\title{
Effect of Seed Rate and Rice Cultivars on Growth and Productivity of Rice (Oryza sativa L.)
}

\author{
Md. Naiyar Ali ${ }^{*}$, Akhilesh $\mathrm{Sah}^{2}$ and T. Izhar \\ ${ }^{1}$ Department of Agronomy, BAU, Ranchi-834 006, Jharkhand, India \\ ${ }^{2}$ (Agronomy) ZRS Chianki, Palamu (BAU) Jharkhand, India \\ ${ }^{3}$ PBG, BAU, Ranchi-834 006, Jharkhand, India \\ *Corresponding author
}

\begin{abstract}
A B S T R A C T
A field experiment was conducted at Birsa Agricultural University farm (Lat:23 ${ }^{0} 17^{\prime} \mathrm{N}$,

Keywords

Seed rate and rice cultivars, Growth and productivity, Rice, Oryza sativa.

Article Info

Accepted: 04 September 2017 Available Online:

10 November 2017 Long: $83^{\circ} 19^{\prime} \mathrm{E}$, Altitude:625 m above MSL) in Kharif 2012 and 2013 with 3 rice hybrids and one high yielding variety viz., DRRH-3, PAC-837,ARIZE TEJ and Lalat having four seed rate in split plot design to assess the effect of varying seed rate and cultivars under aerobic condition. Rice hybrids, PAC 837 gave significantly higher total dry matter accumulation, crop growth rate, net assimilation rate, leaf area index, effective tillers (306 $\mathrm{m}^{-2}$ ), grains per panicle (115), 1000-grain weight $(24.30 \mathrm{~g})$ resulting in higher grain (4.94 t $\mathrm{ha}^{-1}$ ) and straw (7.03 $\left.\mathrm{tha}^{-1}\right)$ yield and harvest index (41.20\%) with net return (Rs. $37790 \mathrm{ha}^{-}$ ${ }^{1}$ ) and benefit cost ratio (1.48) than other rice cultivars. Rice hybrid PAC 837 sown with 25 $\mathrm{kg}$ seed per ha produced higher grain yield $\left(5.2 \mathrm{t} \mathrm{ha}^{-1}\right)$, net return ( $\left.41710 \mathrm{ha}^{-1}\right)$ and benefit: cost ratio (1.70) than other combinations of hybrids or HYV and seed rate except hybrid rice PAC 837 sown with $35 \mathrm{~kg}$ seed ha ${ }^{-1}$. Hence, it may be concluded that cultivation of aerobic rice hybrid PAC 837 with $25 \mathrm{~kg}$ seed per ha may be practiced in Jharkhand for higher productivity and profitability.
\end{abstract}

\section{Introduction}

Rice (Oryza sativa L.), one of most important cereal food crops in the world. Rice provides 32-95 per cent of the dietary energy and contributes 40 per cent of food grain production, providing direct employment to 70 per cent people in rural areas of India. In India, rice is grown in an area of 44 million hectare with total production of 105.24 million tones and average productivity of $2.4 \mathrm{t}$ $\mathrm{ha}^{-1}$. Whereas in Jharkhand rice is cultivated in 17.4 lakhs ha with total production of 31.6 lakhs tones. In the past four decades, our country has made spectacular progress in rice production and productivity. The increasing scarcity of water threatens the sustainability of the irrigated rice production system and hence the food security and livelihood of rice producers and consumers. Aerobic rice is a new way of rice production system in which specially developed, input-response rice varieties are grown in well-drained, nonpuddled, and non-saturated soils without ponded water (Bouman et al., 2005). To realize the maximum possible benefits from aerobic rice, it is essential to adopt recommended package and practices for successful cultivation and maximizing yield of rice under aerobic system. As a result of 
agronomic trials conducted over decades, in multi locations, a package of practices have been optimized for obtaining optimum yield of rice under water scarce conditions. Appropriate agronomic management is thus a pre-requisite to explore the full potential of available resource. Among the various cultural practices suitable rice variety and optimum seed rate are most important for maximizing yield.

Seed rate and row spacing are known to decide plant population per unit area and affects yield attribute formation and yield of aerobic rice. A number of workers have reported that maintenance of a critical level of rice plant population in field was most necessary to maximize grain yields. Seed rate significantly determines the plant population, yield components, yield and relative economic output of aerobic rice. Optimum seed rate with proper row spacing under aerobic rice system provided higher yield. The major yield advantages are related to proper crop establishment, efficient utilization of the natural resources and better weeds suppression due to proper plant population and together with other agronomic cultural practices. But in Jharkhand situation, information on optimum seed rate of suitable hybrid rice for aerobic is very meager.

\section{Materials and Methods}

A field experiment was carried out at rice research farm in western section of Birsa Agricultural University Ranchi, Jharkhand, during the kharif season of 2012 and 2013 to find out the productivity of aerobic rice hybrids under different seed rates. The experimental plot was typical medium land, well-drained soil with fairly uniform topography. Geographically, agronomical research farm of Birsa Agricultural University farm, Ranchi, Jharkhand is situated at $23^{\circ} 17^{\prime}$ $\mathrm{N}$ latitude and $85^{\circ} 10^{\prime} \mathrm{E}$ longitude of with an altitude of $625 \mathrm{~m}$ above the mean sea level.
Experiment was carried out on clay loam soil having low available $\mathrm{N}\left(270.5 \mathrm{~kg} \mathrm{ha}^{-1}\right)$ and available $\mathrm{K}\left(130.8 \mathrm{~kg} \mathrm{ha}^{-1}\right)$ with medium in available $\mathrm{P}\left(19.1 \mathrm{~kg} \mathrm{ha}^{-1}\right)$ and organic $\mathrm{C}(4.7 \mathrm{~g}$ $\mathrm{kg}^{-1}$ ) during kharif 2012 and 2013 at Birsa Agricultural University farm, Ranchi. The experiment was laid out in split plot design with sixteen treatment combinations in three replications. Rice hybrids (DRRH-3, PAC837 and ARIZE TEZ) and Lalat were allotted randomly to four main plots; while different seed rate $\left(15,25,35\right.$ and $\left.45 \mathrm{~kg} \mathrm{ha}^{-1}\right)$ were randomly allotted to four sub plots. Recommended dose of chemical fertilizer 150 $\begin{array}{llllllll}\mathrm{kg} & \mathrm{N} & 75 & \mathrm{~kg} & \mathrm{P}_{2} \mathrm{O}_{5}, & 90 & \mathrm{~kg} & \mathrm{~K}_{2} \mathrm{O}\end{array}$ $\mathrm{ha}^{-1}$ was applied through urea, diammonium phosphate and murate of potash, respectively. Half dose of nitrogen and full amount of phosphorus and potassium were applied in experimental field as basal. Rest half of nitrogen was applied in two equal splits as top dressing i.e. first top dressed at maximum tillering stage and second dressed at panicle primordial initiation stage. The crop was sown on $21^{\text {th }}$ June, 2012 and 20th June 2013. Crop was raised using recommended cultural practices. The yield attributes were estimated from the plants cut from row length and averaged. Test weight (1000grain weight) was estimated from sample randomly drawn from each treatment. The straw yield was computed by deducted the grain yield from the total biological yield.

\section{Results and Discussion}

\section{Growth parameters}

\section{Total tillers per $\mathbf{m}^{2}$ at maturity}

At maturity, rice hybrid PAC 837 produced higher total tillers(327) than Arize Tez (304 $\left.\mathrm{m}^{-2}\right)$, DRRH-3 $\left(268 \mathrm{~m}^{-2}\right)$ and Lalat $\left(250 \mathrm{~m}^{-2}\right)$ respectively. Crop sown with $35 \mathrm{~kg}$ per ha produced 30.12 and 14.15 percent higher total tillers than $15\left(232 \mathrm{~m}^{-2}\right)$ and $25\left(285 \mathrm{~m}^{-2}\right) \mathrm{kg}$ seed per ha (Table 1.) This might be due to 
the fact that PAC 837 had capacity to produce more tiller than other rice hybrids Arize Tez, DRRH-3 and Lalat. The similar results were also reported earlier by Patel (1999). Sharma et al., (1998) also reported that increasing seed rate increased the total tillers of rice but may not be true for productive tillers beyond optimum seed rate.

\section{Crop growth rate (CGR) at 90 days after to maturity}

During 90 days after sowing to maturity, rice hybrids PAC 837 recorded similar crop growth rate as Arize Tez $\left(14.50 \mathrm{~g} \mathrm{~m}^{-2} \mathrm{day}^{-1}\right)$. However, PAC 837 (17.85 $\mathrm{g} \mathrm{m}^{-2}$ day $\left.^{-1}\right)$ produced significantly higher crop growth rate than DRRH $-3\left(8.70 \mathrm{~g} \mathrm{~m}^{-2}\right.$ day $\left.^{-1}\right)$ and Lalat $\left(8.50 \mathrm{~g} \mathrm{~m}^{-2} \mathrm{day}^{-1}\right)$. Increasing seed rate from 15 to $45 \mathrm{~kg}$ per ha increased the crop growth rate of aerobic rice hybrids significantly over its preceding lower seed rate. During 90 days after sowing to maturity, crop sown with $45 \mathrm{~kg}$ seed per ha and $35 \mathrm{~kg}$ seed per ha produced maximum and significantly higher crop growth rate (16.6 and $15.4 \mathrm{~g} \mathrm{~m}^{-2}$ day $^{-1}$ ) than crop sown with 15 $\mathrm{kg}$ seed per ha $\left(9.6 \mathrm{~g} \mathrm{~m}^{-2} \mathrm{day}^{-1}\right)$.

This might be due to more number of total productive tillers per $\mathrm{m}^{2}$ (Table 1 ) in case of former. As well as having higher efficiency to convert solar energy in to chemical energy resulting in total dry matter accumulation (Table 1) in hybrid PAC 837 as DRRH-3.

\section{Leaf area index (LAI)}

Among rice hybrids, PAC 837 recorded maximum and significantly higher leaf area index (4.41) than other rice hybrids, Arize Tez, DRRH-3 and Lalat at 70 days after sowing. Crop sown with $35 \mathrm{~kg}$ seed per ha produced maximum and significantly higher leaf area (4.77) than either lower and higher seed rate at 70 days after sowing respectively (Table 1).

\section{Net assimilation rate (NAR)}

Net assimilation rate of aerobic rice influenced significantly by rice cultivars and seed rate (Table 1). Rice hybrid PAC 837 had maximum and significantly higher net assimilation rate $\left(4.0 \mathrm{~g} \mathrm{~m}^{-2}\right.$ day $\left.^{-1}\right)$ than Arize Tez (3.40 $\mathrm{g} \mathrm{m}^{-2}$ day $^{-1}$ ), DRRH-3 (3.30 $\mathrm{g} \mathrm{m}^{-2}$ day $^{-1}$ ) and Lalat (3.20). Among seed rate, crop sown with $35 \mathrm{~kg}$ seed per ha had higher net assimilation rate $\left(4.0 \mathrm{~g} \mathrm{~m}^{-2}\right.$ day $\left.^{-1}\right)$ than crop sown with lower seed rates. In other words, net assimilation rate recorded under $35 \mathrm{~kg}$ seed per ha was 14.4 and 31.6 percent higher than crop sown with 25 and $15 \mathrm{~kg}$ seed per ha respectively.

\section{Dry matter accumulation in panicles at maturity}

Dry matter accumulation in panicle of aerobic rice was influenced by rice cultivars and seed rate (Table 1). At maturity PAC 837 produced 33.5 and 84.2 percent more panicle dry matter than Arize Tez (615.2 $\left.\mathrm{g} \mathrm{m}^{-2}\right)$, DRRH-3(446 g $\mathrm{m}^{-2}$ ) and Lalat $\left(440.1 \mathrm{~g} \mathrm{~m}^{-2}\right)$. Crop sown with $35 \mathrm{~kg}$ seed per ha accumulated maximum and significantly higher panicle dry matter (712.2 $\mathrm{g} \mathrm{m}^{-2}$ ) than crop sown with lower seed rates at maturity.

\section{Yield attributes and yield}

\section{Productive tiller per $\mathbf{m}^{2}$}

Productive tiller of aerobic rice significantly influenced by cultivars and its seed rate (Table 2). Among rice hybrid, PAC 837 produced maximum and significantly higher number of effective tillers $\left(306 \mathrm{~m}^{-2}\right)$ than other rice hybrids Arize Tez $\left(289 \mathrm{~m}^{-2}\right)$, DRRH-3 (251 $\left.\mathrm{m}^{-2}\right)$ and Lalat(249 $\left.\mathrm{m}^{-2}\right)$. Among seed rate, productive tiller of aerobic rice significantly increased with each increased in seed rate up to $35 \mathrm{~kg}$ per ha and thereafter decreased. Aerobic rice hybrids sown with $35 \mathrm{~kg}$ seed per ha produced 
maximum productive tiller $\left(323 \mathrm{~m}^{-2}\right)$ and was 30.6 and 15.7 percent higher than sown with 15 and $25 \mathrm{~kg}$ seed per ha respectively. Interaction effect of rice hybrids and seed-rate was not significant on productive tiller.

\section{Panicle weight}

Panicle weight of aerobic rice significantly influenced by hybrids and its seed rate (Table 2). Among rice hybrids, PAC 837 produced heaviest panicle $(2.70 \mathrm{~g})$ than other rice hybrids Arize-Tez (2.40g), DRRH-3 (2.3g) and Lalat $(2.25 \mathrm{~g})$.

Among seed-rate, aerobic rice sown with $35 \mathrm{~kg}$ seed per ha produced heavier panicle (2.60g) than the crop sown with $25 \mathrm{~kg}$ seed per ha. Further crop sown with either $15 \mathrm{~kg}$ seed per ha $(2.4 \mathrm{~g})$ or $35 \mathrm{~kg}$ seed $\mathrm{kg}$ per ha $(2.6 \mathrm{~g})$ and $45 \mathrm{~kg}$ seed per ha $(2.5 \mathrm{~g})$ produced almost similar panicle weight.

\section{Grains per panicle}

Grains per panicle of aerobic rice significantly influenced by cultivars and its seed rate (Table 2). Among rice hybrids PAC 837(115) and Arize Tez (107) produced significantly higher grains per panicle than DRRH-3(95). Aerobic rice sown with seed rate of $35 \mathrm{~kg}$ seed per ha produced maximum and significantly higher grains per panicle than all other seed rates.

\section{0 grain weight}

Thousand grain weight of aerobic rice significantly influenced by cultivars and its seed-rate (Table 2). Among rice hybrids, PAC 837 produced boldest grain and was significantly heavier $(24.30 \mathrm{~g})$ than other rice hybrids Arize Tez (22.8g) and DRRH-3 (22.6 g). Among seed rate, 1000-grain weight of aerobic rice increased with each increase in seed rate up to $35 \mathrm{~kg}$ seed per ha and thereafter decreased significantly. Maximum and significantly higher grain weight was observed when crop sown with $35 \mathrm{~kg}$ seed per ha.

This may be due to, higher total tillers, dry matter accumulation, leaf area index, crop growth rate, net assimilation rate resulting in higher yield attributing characters. Nayak et al., (2003) working with hybrids also reported rice hybrid 'PA 6201' had higher number of effective tiller and grains per panicle. Increasing seed rate of aerobic rice increased the yield attributes up to $35 \mathrm{~kg}$ seed per ha and produced higher productive tillers (323 $\left.\mathrm{m}^{-2}\right)$, panicle length $(23.40 \mathrm{~cm})$, grains per panicle (101) and 1000 grain weight (22.0 g) than sown with lower seed rates. Yield attributes which determine the yield are the resultant effect of the vegetative development of the crop. In this case also, crop sown with $35 \mathrm{~kg}$ seed per ha had higher total tillers, crop growth rate and leaf area index resulting in higher yield attributes. Reddy et al., (1986) found that the number of panicles and its length increased with the increasing seeding rates. Similar results have been reported previously by Yu Jun et al., (2007).

\section{Grain yield}

Aerobic rice hybrid, PAC 837 produced maximum and significantly higher grain yield $\left(4.94 \mathrm{t} \mathrm{ha}^{-1}\right)$ than other rice cultivars hybrids, Arize Tez (4.43 $\left.\mathrm{t} \mathrm{ha}^{-1}\right)$, DRRH-3 (3.23t $\mathrm{ha}^{-1}$ ) and Lalat (3.10t ha ${ }^{-1}$ ), which is 11.534 .6 and 37.2 percent higher than aerobic rice cultivars Arize Tez and DRRH-3 Lalat, respectively (Table 2 ).

Grain yield of aerobic rice significantly increased with increasing seed rate up to 35 $\mathrm{kg}$ per ha (4.75t ha $\mathrm{h}^{-1}$ ) and thereafter decreased significantly. Aerobic rice sown with seed rate of $35 \mathrm{~kg}$ per ha produced maximum and was 26.7, 10.7 and 8.6 percent higher than those sown with seed rate of 15,25 , and $45 \mathrm{~kg}$ per ha respectively. 
Table.1 Growth parameters as aerobic rice as influenced by cultivars and seed rates (Pooled data of two years)

\begin{tabular}{|c|c|c|c|c|c|}
\hline Treatments & $\begin{array}{c}\text { Tillers/m² } \\
\text { at } \\
\text { maturity }\end{array}$ & $\begin{array}{l}\mathrm{CGR}(\mathrm{g} / \mathrm{m} 2 / \mathrm{day}) \\
\text { at } 90 \text {-maturity }\end{array}$ & $\begin{array}{c}\text { NAR at } \\
90- \\
\text { maturity }\end{array}$ & $\begin{array}{l}\text { LAI at } \\
70 \text { DAS }\end{array}$ & $\begin{array}{c}\text { Dry matter } \\
\text { accumulation in } \\
\text { panicle at } \\
\text { maturity }\end{array}$ \\
\hline \multicolumn{6}{|l|}{ Cultivars } \\
\hline DRRH-3 & 268 & 8.70 & 3.400 & 4.04 & 446.10 \\
\hline PAC-837 & 327 & 17.85 & 4.000 & 4.40 & 821.75 \\
\hline Arize Tez & 304 & 14.50 & 3.490 & 4.06 & 615.2 \\
\hline Lalat & 250 & 8.50 & 3.20 & 3.80 & 440.1 \\
\hline SEm \pm & 3.55 & 1.84 & 0.132 & 0.03 & 13.40 \\
\hline $\mathrm{CD}(\mathrm{P}=0.05)$ & 13.93 & 7.23 & 0.532 & 0.11 & 52.60 \\
\hline \multicolumn{6}{|c|}{ Seed rates $(\mathrm{kg} / \mathrm{ha})$} \\
\hline 15 & 232 & 9.6 & 3.022 & 3.56 & 526.40 \\
\hline 25 & 285 & 13.2 & 3.478 & 3.80 & 568.70 \\
\hline 35 & 332 & 15.40 & 3.978 & 4.77 & 712.20 \\
\hline 45 & 349 & 16.60 & 3.789 & 4.52 & 703.30 \\
\hline SEm \pm & 5.76 & 1.72 & 0.123 & 0.06 & 17.20 \\
\hline $\mathrm{CD}(\mathrm{P}=0.05)$ & 17.10 & 5.10 & 0.370 & 0.20 & 50.98 \\
\hline
\end{tabular}

Table.2 Yield attributes, yield and harvest index of aerobic rice as influenced by cultivars and seed rates (Pooled data of two years)

\begin{tabular}{|c|c|c|c|c|c|c|c|}
\hline Treatment & $\begin{array}{l}\text { Productive } \\
\text { tiller } / \mathrm{m}^{2}\end{array}$ & $\begin{array}{c}\text { Panicle } \\
\text { weight(g) }\end{array}$ & $\begin{array}{c}\text { Grains } \\
\text { /panicle }\end{array}$ & $\begin{array}{l}\text { 1000- } \\
\text { grain } \\
\text { weight } \\
\text { (g) }\end{array}$ & $\begin{array}{c}\text { Grain } \\
\text { yield } \\
\left(\mathbf{t ~ h a} \mathbf{a}^{-1}\right)\end{array}$ & $\begin{array}{c}\text { Straw } \\
\text { yield } \\
\left(\mathrm{t} \mathrm{ha}^{-1}\right)\end{array}$ & $\begin{array}{c}\text { Harvest index } \\
(\%)\end{array}$ \\
\hline \multicolumn{8}{|l|}{ Cultivars } \\
\hline DRRH-3 & 251 & 2.30 & 95 & 22.60 & 3.23 & 4.88 & 39.60 \\
\hline PAC-837 & 306 & 2.70 & 115 & 24.30 & 4.94 & 7.03 & 41.20 \\
\hline Arize Tez & 289 & 2.40 & 107 & 22.80 & 4.43 & 6.35 & 41.10 \\
\hline Lalat & 249 & 2.25 & 85 & 23.40 & 3.10 & 4.50 & 38.20 \\
\hline SEm \pm & 3.71 & 0.05 & 2.05 & 0.27 & 0.03 & 0.03 & 0.23 \\
\hline $\mathrm{CD}(\mathrm{P}=0.05)$ & 14.56 & 0.20 & 8.08 & 1.05 & 0.12 & 0.10 & 0.90 \\
\hline \multicolumn{8}{|l|}{ Seed rate $(\mathrm{kg} / \mathrm{ha})$} \\
\hline 15 & 224 & 2.40 & 101 & 21.60 & 3.48 & 5.48 & 38.20 \\
\hline 25 & 272 & 2.30 & 101 & 24.0 & 4.24 & 5.98 & 41.50 \\
\hline 35 & 323 & 2.6 & 118 & 25.30 & 4.75 & 6.74 & 41.40 \\
\hline 45 & 309 & 2.5 & 102 & 23.40 & 4.34 & 6.15 & 41.30 \\
\hline SEm \pm & 6.77 & 0.06 & 1.90 & 0.42 & 0.10 & 0.12 & 0.63 \\
\hline $\mathrm{CD}(\mathrm{P}=0.05)$ & 20.11 & 0.18 & 5.66 & 1.25 & 0.28 & 0.36 & 1.87 \\
\hline
\end{tabular}


Table.3 Economics of aerobic rice as influenced by cultivars and seed rates (Pooled data of two years)

\begin{tabular}{|c|c|c|c|c|}
\hline Treatment & $\begin{array}{c}\text { Cost of } \\
\text { cultivation } \\
\text { (Rs. ha }^{-1)}\end{array}$ & $\begin{array}{c}\text { Gross return } \\
\left(\text { Rs. } \text { ha }^{-1}\right)\end{array}$ & $\begin{array}{c}\text { Net return } \\
\left(\text { (Rs.ha }^{-1}\right)\end{array}$ & $\begin{array}{c}\text { Benefit cost } \\
\text { ratio }\end{array}$ \\
\hline \multicolumn{5}{|l|}{ Cultivars } \\
\hline DRRH-3 & 25690 & 42170 & 16470 & 0.64 \\
\hline PAC 837 & 25690 & 63480 & 37790 & 1.48 \\
\hline Arize Tez & 25690 & 56970 & 31270 & 1.23 \\
\hline Lalat & 24550 & 41270 & 16720 & 0.68 \\
\hline SEm \pm & & 292 & 292 & 0.01 \\
\hline $\mathrm{CD}(\mathrm{p}=0.05)$ & & 1146 & 1146 & 0.04 \\
\hline \multicolumn{5}{|c|}{ Seed rate $(\mathrm{kg} / \mathrm{ha})$} \\
\hline 15 & 22090 & 45730 & 23640 & 1.07 \\
\hline 25 & 24490 & 54410 & 29918 & 1.22 \\
\hline 35 & 26890 & 60930 & 34040 & 1.27 \\
\hline 45 & 29290 & 55744 & 26450 & 0.90 \\
\hline SEm \pm & & 927 & 927 & 0.04 \\
\hline $\mathrm{CD}(\mathrm{p}=0.05)$ & & 2750 & 2750 & 0.12 \\
\hline
\end{tabular}

Interaction effect of rice hybrids and seed-rate was not significant in grain yield.

\section{Straw yield}

Aerobic rice hybrid, PAC837 produced maximum and significantly higher straw yield $\left(7.03 \mathrm{tha}^{-1}\right)$ than other aerobic rice hybrid, Arize Tez (6.35t ha' $\left.{ }^{-1}\right)$ DRRH-3 (4.88t ha $\left.{ }^{-1}\right)$ and Lalat $\left(4.5 \mathrm{t} \mathrm{ha} \mathrm{h}^{-1}\right)$. Straw yield of aerobic rice significantly increased with increasing seed rate up to $35 \mathrm{~kg}$ per ha and thereafter decreased significantly. Aerobic rice sown with seed rate $35 \mathrm{~kg}$ per ha produced maximum $\left(6.74 \mathrm{tha}^{-1}\right)$.

Interaction effect of aerobic rice hybrid and seed rate was not significant on the production of straw yield.

\section{Harvest index}

Harvest index aerobic rice significantly influenced by hybrids and its seed rate (Table 2). Aerobic rice hybrid, PAC 837 recorded maximum and significant higher harvest index $(41.20 \%)$ than other ricecultivars. Among seed rate, harvest index recorded with seed rate of 25,35 and $45 \mathrm{~kg}$ seed per ha were statistically similar among themselves and was significantly higher than the seed rate of $15 \mathrm{~kg}$ per ha. Maximum harvest index (41.5\%) was recorded with seed rate of $25 \mathrm{~kg}$ per ha while the minimum with seed rate of $15 \mathrm{~kg}$ per ha.

\section{Economics}

\section{Gross return}

Gross return of aerobic rice hybrids were significantly influenced by seed rates (Table 3 ). Among hybrids, PAC 837 gave highest and significantly higher (Rs. $63480 \mathrm{ha}^{-1}$ ) gross return than other rice hybrids Arize Tez (Rs.56970 ha-1) DRRH-3 (Rs.42170 ha ${ }^{-1}$ ) ) and Lalat (Rs.41270 ha-1). Further, rice Arize Tez gave significantly higher gross return than DRRH-3 and Lalat.

Increasing seed rates significantly increased the gross return up to $35 \mathrm{~kg}$ seed ha ${ }^{-1}$ (Rs. 60930 $\left.\mathrm{ha}^{-1}\right)$, thereafter it decreased significantly. Rice hybrid, PAC 837 sown with $35 \mathrm{~kg}$ seed per ha 
(Table 3) recorded maximum and significantly higher gross return (Rs. $69130 \mathrm{ha}^{-1}$ ) than all other combinations of hybrids and seed rates except PAC 837 sown with $25 \mathrm{~kg}$ seed per ha (Rs. 66200), 45kg per ha (Rs. $65730 \mathrm{ha}^{-1}$ ) and Arize Tez sown with $35 \mathrm{~kg}$ per seed ha (Rs. $65070 \mathrm{ha}^{-1}$ ).

\section{Net return}

Net return of aerobic rice also followed the pattern of gross return and grain yield (Table 3 ). Hybrid rice PAC 837 gave significantly higher (Rs. 37790 ha $^{-1}$ ) net return than other rice hybrids Arize Tez (Rs. 31270 ha $^{-1}$ ), DRRH-3 (Rs. 16470 $\mathrm{ha}^{-1}$ ) and Lalat (Rs.16720 ha ${ }^{-1}$ ). Further hybrid rice Arize Tez also gave significantly higher net return than DRRH-3 and Lalat.

Among seed rates, increasing seed rate increased the net return up to $35 \mathrm{~kg}$ seed per ha (Rs.34040 $\mathrm{ha}^{-1}$ ) thereafter it decreased. Rice hybrid PAC 837 sown with $35 \mathrm{~kg}$ seed per ha recorded maximum and significantly higher net return (Rs.42240 ha ${ }^{-1}$ ) than all other combinations of hybrids and seed rates except PAC 837 sown with $25 \mathrm{~kg}$ seed per ha (Rs. $41710 \mathrm{ha}^{-1}$ ) and Arize Tez with $35 \mathrm{~kg}$ seed per ha (Rs.38170 ha-1).

\section{Benefit: cost ratio}

Benefit: cost ratio is the ratio of net return and cost of cultivation. Benefit: cost ratio of aerobic rice significantly influenced by hybrids and seed rates (Table 3 ).

Hybrid rice PAC 837 (1.48) recorded significantly higher benefit: cost ratio than rest of rice cultivars. Among seed rates, crop sown with $35 \mathrm{~kg}$ seed per ha (1.27) being similar to crop sown with $25 \mathrm{~kg}$ seed per ha (1.22) was significantly higher than other seed rates.
This might be due to higher grain and straw yield (Table 2) of the crop. It confirmed the result of Power and Deshpande (2001) and Kewat et al., (2002).

\section{References}

Bouman, B.A.M., Peng, S., Castaneda, A.R. and Visperas, R.M. 2005. Yield and water used of tropical aerobic rice systems. Agic. Water Manag, 74: 87-105.

Kewat, M. L.; Agrawal, S. B.; Agrawal, K. K. and Sharma R. S. 2002. Effect of divergent plant spacing and age of seedlings on yield and economics of hybrid rice. Indian J. Agron., 47 (3): 367371

Nayak, B. C; Dalei, B. B. and Chodhury, B. K. 2003. Response of hybrid rice to date of planting, spacing and seedling rate during wet season. Indian J. Agron., 48(3): 112114.

Powar. S. L. and Deshpande, V. N. 2001. Effect of integrated agro-technology on Sahyadri hybrid rice in medium black sail in high rainfall area. J. Maharashtra Agric. Univ., 26 (3): 272-276.

Reddy, G. V. and Reddy, P. S. 1986. Effect of time of planting and spacing on IET-2508 in puddled soil during dry season. Oryza, 23 (1): 53-55.

Sharma, A. R. and Ghosh, A. 1998. Optimum seed rate and nitrogen fertilizer requirement of rice under semi-deep water ecosystem. Journal of Agronomy and Crop science. 181(3): 167-

Yu Jun, Guo Xingqiang, and Xie Guanghui. 2007. Yield of aerobic rice at different seeding rates in North China. Journal of China Agricultural University. 6: 127132.

\section{How to cite this article:}

Md. Naiyar Ali, Akhilesh Sah and Izhar, T. 2017. Effect of Seed Rate and Rice Cultivars on Growth and Productivity of Rice (Oryza sativa L.). Int.J.Curr.Microbiol.App.Sci. 6(11): 61-67. doi: https://doi.org/10.20546/ijcmas.2017.611.008 